Vol 2 No 2 Desember 2021

Jurnal AlphaEuclidEdu

Received: 23/09/2021; Resived: 01/10/2021; Accepted: 27/12/2021

\title{
EKSPLORASI SIKAP MAHASISWA PENDIDIKAN MATEMATIKA DALAM PEMBELAJARAN MATEMATIKA
}

\author{
Yulis Jamiah \\ Prodi Pendidikan Matematika, FKIP Universitas Tanjungpura \\ E-mail: vulis.jamiah@fkip.untan.ac.id
}

\begin{abstract}
In essence, an appropriate and interesting learning process for students will encourage them to optimize their potential. On the other hand, if educators/lecturers carry out the process of learning activities that are less creative and less innovative, can you imagine what will happen? The students interacting in the learning process are not like empty bottles, but they have brought cultural values brought from their families and communities. Wise educators must be able to understand the diversity of their attitudes in the learning process. Exploration of student attitudes in learning mathematics can be used as a vehicle to understand student character. Attitude is a readiness to react to objects in a certain environment and as an appreciation of the object. There are three main components that together form a complete attitude, namely: a) belief in an object, b) emotional life or evaluation of an object, and c) tendency to act. Understanding of student attitudes will make it easier to interact in the learning process.
\end{abstract}

Keywords: Attitude, Mathematics Learning.

\section{Pendahuluan}

Matematika merupakan ilmu yang memegang peranan cukup penting dalam pengembangan ilmu pengetahuan dan teknologi. Oleh karena itu agar matematika dapat berperan aktif dalam kehidupan yang terus berkembang ini, maka penguasaan terhadap matematika merupakan suatu keharusan. Penguasaan terhadap matematika ini dapat menjadikan seorang untuk berpikir dan bernalar secara teratur, logis dan konsisten. Untuk menguasai matematika dapat dilakukan melalui jalur pendidikan formal maupun non formal, melalui jalur pendidikan formal inilah akan mengenal terjadinya proses kegiatan pembelajaran di kelas.Pendidikan formal ini ada 3 aspek yang merupakan sasaran dalam proses kegiatannya, yaitu aspek kognitif, aspek afektif dan aspek psikomotor. Dalam aspek afektif terdapat satu komponen yang cukup penting dan mempengaruhi belajar mahasiswa, yakni komponen sikap.

Sikap mahasiswa menyenangi matematika, maka sikapnya itu tentu mempengaruhi prilakunya terhadap matematika. Sikap yang ditunjukkan sebaliknya, tentu merupakan salah satu hambatan dalam belajar matematika untukmencapai prestasi belajar yang tinggi. Oleh karena itu seorang pendidik/dosen tidak hanya menitikberatkan pada aspek kognitif dan psikomotor tetapi aspek afektif terutamasikap. Karena dengan terbentuknya sikap yang positif terhadap matematika sangat membantu mahasiswa menguasai materi matematika dengan baik.

Penguasaan materi matematika yang baik, penyajiannya dalam pembelajaran matematika harus memahami karakteristiknya, yaitu: 1) pembelajaran matematika berjenjang (bertahap), artinya materi pembelajaran diajarkan secara berjenjang atau bertahap dari hal konkrit ke abstrak, hal yang sederhana ke kompleks, atau dari konsep mudah ke konsep yang lebih sukar; 2) pembelajaran matematika mengikuti metoda spiral, artinya setiap mempelajari konsep baru perlu memperhatikan konsep atau bahan yang telah dipelajari sebelumnya; 3) pembelajaran matematika menekankan pola pikir deduktif, yang harus dapat dipilihkan pendekatan yang cocok dengan kondisi pembelajar; dan 4) pembelajaran matematika menganut kebenaran konsistensi, artinya 
Vol 2 No 2 Desember 2021

Jurnal AlphaEuclidEdu

Received: 23/09/2021; Resived: 01/10/2021; Accepted: 27/12/2021

kebenaran-kebenaran dalam matematika pada dasarnya merupakan kebenaran konsistensi, tidak bertentangan antara kebenaran suatu konsep dengan yang lainnya (Soedjadi, 2004); Bambang, 2007).

Berdasarkan pengalaman dan hasil pengamatan penulis selama memberikan perkuliahan maupun pembimbingan tiga tahun terakhir ini, terungkap suatu indikasi bahwa profil kelulusan mahasiswa lebih dominan mementingkan hasil akhir dalam aspek pengetahuan, dan kurang memperhatikan aspek sikap. Indikasi ini diperlihatkan dengan prilaku ingin cepat atauinstan untuk memperoleh sesuatu yang diinginkannya.

Sikap mahasiswa menyenangi matematika, maka sikapnya itu tentu mempengaruhi prilakunya terhadap matematika. Sebaliknya sikap tidak menyukai matematika merupakan salah satu hambatan dalam belajar matematika. Oleh karena itu, seorang dosen untuk mewujudkankemampuan minimal yang harus dikuasai mahasiswa tidak hanya menitikberatkan padaaspek pengetahuan saja, tetapi harus menyeimbangkan aspek ketrampilan dan aspek sikap. Karena dengan terbentuknya sikap yang positif terhadap matematika, hal ini sangat membantu mahasiswa dalam menguasai materi.

Hasil pengamatan tiga tahun terakhir yang penulis lakukan, mengindikasikan hasilyang kontradiktif dengan hasil penelitian tahun 2006, yakni mendeskripsikan sikap mahasiswa semester VI Jurusan PMIPA Program Studi Pendidikan Matematikamelalui pembelajaran matematika dalammata kuliah Struktur Aljabar. Berdasarkan 34pernyataan dengan muatan tentang sikap, yang dipilih oleh 31 mahasiswa, menunjukkan hasil sebagai berikut: 1) terdapat 3,22 \% (satu mahasiswa) menyatakan sikap sangat negatip; 2) terdapat3,22\% (satu mahasiswa) menyatakan sikap negatip; 3 ) terdapat 6,34 \% (dua mahasiswa) menyatakan sikap ragu-ragu; dan 4) terdapat 54,83 \% (17 mahasiswa) menyatakan sikap positif; serta 5) terdapat 32,25 \% (10 mahasiswa) menyatakan sikap sangat positip.Hasil tersebut, sebagian besar mahasiswa $( \pm 87 \%)$ memberikan tanggapan bahwa mahasiswa dalam mempelajari matematika di semester enam, khususnya mata kuliahStruktur Aljabar bersikap positip dan sangat positip. Hal ini memberikan makna bahwa sikap mahsiswa, seperti: sangat senang, tanggung jawab, merespon dengan baik terhadap pembelajaran matematika dalam mata kuliah Struktur Aljabar.

Faktor yang mempengaruhi perolehan belajar, di antaranya adalah sikap. Menurut Azwar, (1988), Sikap sebagai derajat perasaan positif atau negatf yang dikaitkan dengan suatu objek psikologis. Sikap merupakan sesuatu yang dipelajari, dan sikap menentukan bagaimana individu bereaksi terhadap situasi serta menentukan apa yang dicari individu dalam kehidupan. Triandis (Slameto, 1991: 191) mendefinisikan sebagai berikut. An attitude is an idea charged with emation which predisposes a class of action to a particular class of social situations. Sikap mempunyai persamaan unsur, yaitu adanya kesediaan untuk berespon terhadap suatu situasi. Sikapterbentuk melalui beberapan cara, diantaranya: 1) melalui pengalaman yang berulang-ulang, 2) melalui imitasi/peniruan, 3) melalui sugesti, dan 4) melalui identifikasi(Slameto, 1991: 192).

Sikap merupakan kesiapan untuk bereaksi terhadap objek di lingkungan tertentu sebagai suatu penghayatan terhadap objek. Allport (Notoatmodjo, 2007) menjelaskan bahwa sikap itu mempunyai tigakomponen pokok yang secara bersama-samamembentuk sikap yang utuh, yakni: a) kepercayaan (keyakinan), ide dan konsep terhadap suatu objek, b) kehidupan emosional atau evaluasi terhadap suatu objek, dan c) kecenderungan untuk bertindak. Sikap yang utuh ini, pengetahuan, pikiran, keyakinan dan emosi memegang peranan penting. Selain adanya komponen pokok, sikap juga terbagai 
Vol 2 No 2 Desember 2021

Jurnal AlphaEuclidEdu

Received: 23/09/2021; Resived: 01/10/2021; Accepted: 27/12/2021

tingkatannya, yakni: i) menerima artinya subjek memperhatikan stimulus yang diberikan, ii) merespon artinya memberikan jawaban apabila ditanya, mengerjakan dan menyelesaikan tugas yang diberikan, iii) menghargai artinya mengajak orang lain untuk mengerjakan ataumendiskusikan suatu masalah, dan iv) bertanggung jawab atas segala sesuatu yang telah dipilihnya dengan segala risiko merupakan sikap yang paling tinggi.

Pengindikasian sikap seseorang merasa senang atau tidak senang terhadap matematika, pengkajiannya ini tertuang dalam disposisi matematis. Menurut Kilpatrick, Swafford, dan Findell (2001) menamakan disposisi matematis sebagai productive disposition (disposisi produktif), yakni pandangan terhadap matematika sebagai sesuatu yang logis, dan mengahasilkan sesuatu yang berguna. Lebih lanjut dikatakannya, disposisi matematika adalah kecenderungan; i) memandang matematika sesuatu yang dapat dipahami; ii) merasakan matematika sebagai sesuatu yang berguna dan bermanfaat; iii) meyakini usahayang tekun dan ulet dalam mempelajari matematika akan membuahkan hasil; dan iv) melakukan perbuatan sebagai pebelajar dan pekerja matematika yang efektif. Polking (dalam Sumarmo, 2010) mengemukakan bahwa komponen disposisi matematik, yakni: 1) rasa percaya diri dalam menggunakan matematika, memecahkan masalah, memberi alasan dan mengkomunikasikan gagasan; 2) fleksibilitas dalam menyelidiki gagasan matematik dan berusaha mencari metoda alternatif dalam memecahkan masalah; 3) tekun mengerjakantugas matematik; 4) minat, rasa ingin tahu (curiosity), dan dayatemu dalam melakukan tugas matematik; 5) cenderung memonitor, merepleksikan performance dan penalaran mereka sendiri; 6) menilai aplikasi matematika ke situasi lain dalam matematika dan pengalaman seharihari; 7) apresiasi (appreciation) peran matematika dalam kultur dan nilai, matematika sebagai alat danbahasa.

Berdasarkan uraian di atas, tertuanglah pertanyaan yang akan dibahas dalam tulisan ini, yaitu: Bagaimana mengeksplorasi sikap mahasiswa pendidikan matematika dalam pembelajaran matematika? Dengan tujuan memperoleh gambaran secara teoritis kecendrungan sikap mahasiswa pendidikan matematika dalam pembelajaran matematika.

\section{Metode Penelitian}

Pengkajian yang digunakan untuk menjawab pertanyaan "bagaimana mengeksplorasi sikap mahasiswa pendidikan matematika dalam pembelajaran matematika?". Pengkajian bersifat kualitatif bertumpu pada suatu fokus masalah. Menurut Moleong (2007: 93) masalah merupakan suatu keadaan yang bersumber dari hubungan antara dua faktor atau lebih yang menghasilkan situasi yang menimbulkan tanda tanya dan dengan sendirinya memerlukan upaya untuk mencari suatu jawaban. Fokus kajiannya adalah: 1) sikap yang utuh terbentuk dari tiga komponen pokok, yakni: a) kepercayaan (keyakinan), ide dan konsep terhadap suatu objek, b) kehidupan emosional atau evaluasi terhadap suatu objek, dan c) kecenderungan untuk bertindak; 2) sikap berdasarkan tingkatannya, yakni: i) menerima artinya subjek memperhatikan stimulus yang diberikan, ii) merespon artinya memberikan jawaban apabila ditanya, mengerjakan danmenyelesaikan tugas yang diberikan, iii) menghargai artinya mengajak orang lain untuk mengerjakan atau mendiskusikan suatu masalah, dan iv) berrtanggung jawab atas segala sesuatu yang telah dipilihnya dengan segala risiko merupakan sikap yang paling tinggi. 
Vol 2 No 2 Desember 2021

Jurnal AlphaEuclidEdu

Received: 23/09/2021; Resived: 01/10/2021; Accepted: 27/12/2021

Penjaringan dan pengumpulan data menggunakan intrumen non-tes, yakni angket. Menurut Sanjaya (2013:255), angket merupakan instrumen berupa daftar pertanyaan atau pernyataan secara tertulis yang harus dijawab atau diisi oleh responden sesuai dengan petunjuk pengisian. Penyusunan angket ini, memerlukan format kisi-kisi yang memuat definisi secara teoritis; definisi konseptual; definisi operasional; indikator; dan item pernyataan favorable/unfavorable. Setiap item pernyataan dalam angket diberikan pilihan tanggapan dengan menggunakan skala likert,yakni Sangat Setuju (SS); Setuju (S); Ragu- Ragu (R); Tidak Setuju (TS); dan SangatTidak Setuju (STS).

Beberapa kriteria yang harus diperhatikan dalam menyusun pernyataan untuk mengungkapkan sikap seseorang terhadap suatu objek, sehingga dapat memperoleh jawaban yang benar-benar diharapkan, setiap pernyataan yang diajukanhendaknya tidak meragukan dan menimbulkan tafsiran lain. Edward (1969: 13-14) mengemukakan kriteria tersebut sebagai berikut: a) arahkanlah pernyataan yang dikemukakan yang berhubungan dengan kondisi aktual, tidak mengungkapkan hal-hal yang sifatnya basi; b) hindarkan pernyataan yang merupakan suatu fakta atau dapat dianggap fakta, sehingga tidak mengungkapkan sikap; c) pernyataan hendaknya tidak mengandung arti yang bermacam-macam sehingga membingungkan; d) pernyataan hendaknya relevan dengan aspek psikologi yang akan dievaluasi; e) hindarkan pernyataan yang akan disetujui oleh semua responden, atau sebaliknya; f) susunlah pernyataan dalam bahasa yang sederhana, jelas dan langsung pada pokok masalah serta disajikan diusahakan singkat; g) tiap pernyataan diusahakan hanya memuat satu pokok pikiran; h) hindari kata-kata yang sifatnya universal, seperti semua, setiap, selalu, tak satupun, atau tak pernah sehingga tidak menimbukan keraguan; i) hati-hati menulis pernyataan dengan menggunakan kata "hanya" dan sejenisnya; j) usahakan menyusun pernyataan dengan kalimat tunggal; k) gunakan kata-kata yang sudah banyak dikenal agar tidak menyesatkan; dan 1) hindarkan menggunakan pernyataan yang mengandung kata negatif lebih dari satu kali.Data hasil angket yang diperolah berasal dari tanggapan mahasiswa, dianalisismenggunakan peskoran sesuai dengan skalalikert.

Analisis ini menyatakan kesetujuan dan ketidak setujuan responden pada lima kategori pilihan dengan tujuan untuk mempertegas pilihan responden. Kelima kategori tersebut, yakni item favorable: skor 4 untuk memilih "Sangat Setuju (SS)"; skor 3 untuk memilih "Setuju (S)"; skor 2 untukmemilih "Ragu-Ragu (R)"; skor 1 untuk memilih "Tidak Setuju (TS)"; dan skor 0untuk memilih "Sangat Tidak Setuju (STS)". Sedangkan untuk item unfavorable berlaku penskoran kebalikan dari favorable. Penskalaan dengan metode likert dalamanalisis ini berbantukan deviasi normal dengan tujuan untuk memberi bobot yang tertinggi bagi kategori jawaban yang favorabel dan memberi bobot rendah pada jawaban yang tidak favorable (Syaifuddin, 2010:141).

Proses penentuan nilai skala, yaitu: 1) membuat tabel distribusi responden; 2) membuat tabel nilai skala kategori jawaban untuk setiap pernyataan, dengan tahapan untuk menentukan nilai skala, di antaranya: a) menghitung frekuensi (f) jawaban responden untuk masing-masing kategori respon; b) menghitung proporsi (p) masingmasing respon dengan cara membagi frekuensi pada tiap respon dengan jumlah responden keseluruhan; c) menghitung proporsi kumulatif (pk); d) menghitung titik tengah proporsi kumulatif (pkt); e) mencari nilai $\mathrm{z}$ dari tabel deviasi normal; $\mathrm{f}$ ) menentukan titik nol pada respon paling kiri atau paling rendah; dan g) melakukan pembulatan harga z. Selanjutnya melakukan tahapan untuk setiap item pernyataan: 3) 
Vol 2 No 2 Desember 2021

Jurnal AlphaEuclidEdu

Received: 23/09/2021; Resived: 01/10/2021; Accepted: 27/12/2021

menentukan interval untuk menggolongkan responden pada kategori yang sesuai dengan pilihannya; dan 4) menentukan skala responden.

\section{Hasil dan Pembahasan}

Pendidik/dosen yang mencintai profesinya demi kemajuan mahasiswa tidak akan merobohkan pilar pembelajaran. Selain itu, dosen yang profesional tentu selalu mencerminkan prilaku yang dapat di tauladani oleh mahasiswa, seperti berbahasa dengan bijak, dengan baik dan benar, dengan bahasa yang indah-indah, serta dengan sopansantun akan menumbuhkan pikiran dan sikappositif, menumbuhkan keakraban dan mempererat persaudaraan, menumbuhkan simpati dan empati, menjauhkan lawan bicara dari rasa tertekan atau terintimidasi (Chairil, 2012:9). Prilaku-prilaku dosen yang dipaparkan tersebut dapat mempengaruhi sikap dan prilaku serta kemampuan belajar mahasiswa.

Tujuan pembelajaran bukanlah penguasaan materi semata, namun lebih jauh proses penguasaan materi dapat membentuk prilaku mahasiswa itu sendiri. Proses pembelajaran untuk membentuk prilaku mahasiswa yang baik sangat dipengaruhi oleh kondisi kewibawaan dan kewiyataan yang ada pada diri dosen selaku pendidik. Karena kondisi tersebut merupakan pilar pembelajaran. Kewibawaan dapat tercipta, jika dosen mampu membangun sentuhan yang tinggi terhadap mahasiswa sehingga terciptanya rasa aman dan nyaman bersama pendidiknya. Untuk mengkondisikan rasa aman dan nyaman dalam belajar ini, sangat perlu memperhatikan unsur-unsur kewibawaan, yaitu: 1) pengakuan dan penerimaan; 2) kasih sayang dan kelembutan; 2) penguatan; 4) tindakan tegas yang mendidik; dan 5) pengarahan dan keteladanan. Sementara unsurunsur yang ada pada kewiyataan, yaitu: 1) penguasaan materi pembelajaran; 2) penerapan metode pembelajaran; 3) penggunaan alat bantu pembelajaran; 4) pengembangan lingkungan pembelajaran; dan 5) penyelenggaraan penilaian pembelajaran (Phil Y.K., 2012:110).

Selanjutnya, membangun sikap mahasiswa yang mumpuni setidaknya memerlukan tiga hal, yaitu: keteladanan, pembiasaan, dan pengontrolan. Keteladan, dapat diwujudkan dalam proses pembelajaran dengan menginternalisasikan nilai-nilai, seperti: keberanian, kejujuran, percaya diri, tanggungjawab, kerendahan hati, saling menghargai. Pembiasaan, prosesnya dapat diwujudkan melalui membiasakan dengan mengulang-ulang nilai yang diinternalisasikan dalam diri seseorang. Pengontrolan, prosesnya senantiasa memberikan penghargaan (reward) pada mahasiwa yang berprestasi sebagai penyemangat/motivator, dan pemberian sanksi (punishment) bagi mereka yang kurang memberikan perhatian (Arif Rachman, 2015). Artinya, membangun sikap tidak lepas dari kesadaran dari tugas pendidik/dosen yang bukan hanya membuat pembelajar menjadi pandai, tetapi juga membekali mereka dengan nilai-nilaikehidupan untuk mempersiapkan dalam menghadapi tantangan masa depan.

Penginternalisasian nilai-nilai ini mempengaruhi pembentukan kepribadian atau karakter mahasiswa. Lickona (1991) menyatakan pandangannya bahwa karakter terbentuk melalui proses knowing the good, feeling the good, acting the good. Pandangan ini memberikan implikasi bahwa dalam pembentukan dan pengembangan karakter melalui proses pemahaman, menghayati/meyakini, dan mewujudkan nilai karakter dalam perbuatan. Selanjutnya, Kilpatrick (Muslich, 2011:133) menyatakan bahwa seseorang mempunyai kebajikan (moral knowing) namun harus mampu 
Vol 2 No 2 Desember 2021

Jurnal AlphaEuclidEdu

Received: 23/09/2021; Resived: 01/10/2021; Accepted: 27/12/2021

mewujudkan pemahamannya melalui pembiasaan menjadi perilaku baik (moralaction). Pewujudan moral knowing menjadi moral action memerlukan moral feeling. Maksudnya, kemampuan meyakini apa yang diketahui seseorang terhadap kebajikan itu mampu merubah pengetahuannya menjadi perilaku baik. Kemampuan terhap moral knowing dan moral feeling menjadi moral action memerlukan latihan atau pembiasaan. Penanaman nilai-nilai moral kowing, moral feeling dan moral action diharapkan dapat membentuk kepribadian seseorang yang mempunyai perilaku mandiri dapat memutuskan tindakan yang berasal dari kebajikan dalam dirinya. Sehingga sikap dan tindakan yang dilakukan mengarah pada pembentukan dan pengembangan kepribadian atau karakter seseorang.

\section{Kesimpulan}

Sikap atau perilaku pengertiannya secara umum dianggap sama, hal ini ada benarnya karena sikap dan perilaku sama sama merupakan respon yang ditunjukkan dengan reaksi sesuai karakter dari seseorang yang melakukannya. Namun dalam psikologi terdapat perbedaan makna antara sikap dan perilaku. Manifestasi sikap tidak dapat langsung dilihat, melainkan ditafsirkanterlebih dahulu sebagai tingkah laku, sikap sering dihadapkan pada rangsang sosial dan reaksi yang bersifat emosional. Dengan kata lain, bahwa sikap bukan merupakan suatu tindakan melainkan merupakan kecenderungan perilaku.

Pengeksplorasian sikap mahasiswa dalam pembelajaran matematika dapat digunakan sebagai wahana untuk memahami karakter mahasiswa. Sikap itu merupakan kesiapan untuk bereaksi terhadap objek di lingkungan tertentu dan sebagai suatu penghayatan terhadap objek. Terdapat tiga komponen pokok yang secara bersama-sama membentuk sikap yang utuh, yakni: a) kepercayaan terhadap suatu objek, b) kehidupan emosional atau evaluasi terhadap suatu objek, dan c) kecenderungan untuk bertindak. Pemahaman terhadap sikap mahasiswa akan memudahkan untuk berinteraksi dalam proses pembelajaran.

Perilaku ketauladan, pembiasaan dan koreksi atau kontrol sangat diperlukan untuk menegakkan pilar pembelajaran matematika,karena prilaku tersebut akan muncul dan memancarkan nilai edukatif. Nilai tersebut selalu terpancar, jika pendidik/dosen tidakhanya bertindak sebagai pentransfer ilmu pengetahuan intelektual subjek didiknya saja,melainkan pendidik yang dapat memberdayakan dan mengembangkan pengetahuan subjek didiknya secara utuh/komprehensip.

\section{Referensi}

Arif Rachman (2015). Guru Berdasarkan Catatan Ukim Komarudin, Penerbit Erlangga. Bambang, H. (2007). Representasi dalam Pembelajaran Matematika. Pontianak: STAIN Pontianak Press.

Chairif E. (2012). Peranan Bahasa Melayu dalam MembangunKarakter Bangsa, Bahan SeminarNasional di Hotel AstonPontianak Tgl 5-6 Juni 2012.

Kilpatrick, J., Swafford, J., \& Findell, B. (2001). Adding it up: Helping children learn mathematics. Washington, DC. : NationalAcademy Press.

Lickona, T. (1991). Educating For Character How Our Schools Can Teach Respect AndResponsibility. New York : Simon\& Schuster, Inc.

Muslich, M. (2011).Pendidikan Karakter Menjawab Tantangan Krisis 
Vol 2 No 2 Desember 2021

Jurnal AlphaEuclidEdu

Received: 23/09/2021; Resived: 01/10/2021; Accepted: 27/12/2021

Multidimensional. Jakarta:PT. Bumi Aksara.

Soedjadi, R. (2004). Designing Instruction of Values in SchoolMathematics, Surabaya: FPMIPAUNESA.

Sumarmo, U. 2010. Berfikir dan Disposisi Matematik: apa, Mengapa, dan Bagaimana dikembangkan pada Peserta Didik. https://www.scribd.com/doc/763 53753/Berfikir-DanDisposisi- Matematik-Utari [on-line diunduh12-06-2021].

Yulis J., dkk (2013). Pengembangan Model Pembelajaran Matematika Humanis Sederhana Berbasis Pendidikan Karakter BagiMahasiswa Pendidikan Matematika FKIP UntanPontianak. Laporan Penelitian. , (2006). Deskripsi SikapMahasiswa Semester VI Jurusan PMIPA Program Studi Pendidikan Matematika Terhadap Mata Kuliah Struktur Aljabar.Laporan Penelitian. 